\title{
Production of added value bacterial lipids through valorisation of hydrocarbon-contaminated cork waste
}

\author{
A.R. Castro, M. Guimarães, J.V. Oliveira, M.A. Pereira * \\ CEB-Centre of Biological Engineering, University of Minho, 4710-057 Braga, Portugal
}

\section{H I G H L I G H T S}

- Hydrocarbon-contaminated cork sorbents are conventionally submitted to costly hazardous wastes treatments.

- Rhodococcus opacus B4 was able to efficiently treat hexadecane-contaminated cork wastes with concomitant lipids production.

- Triacylglycerol (TAG) was the main neutral lipid produced and palmitic acid was the predominant fatty acid present.

- Produced lipid-rich biomass can be used as feedstocks for biofuels production.

\section{A R T I C L E I N F O}

\section{Article history:}

Received 15 March 2017

Received in revised form 20 June 2017

Accepted 25 June 2017

Available online $\mathrm{xxxx}$

Editor: Simon Pollard

\section{Keywords:}

Rhodococcus opacus B4

Neutral lipids

Cork sorbents

Hydrocarbons

Biomethane

Valorisation

\section{G R A P H I C A L A B S T R A C T}

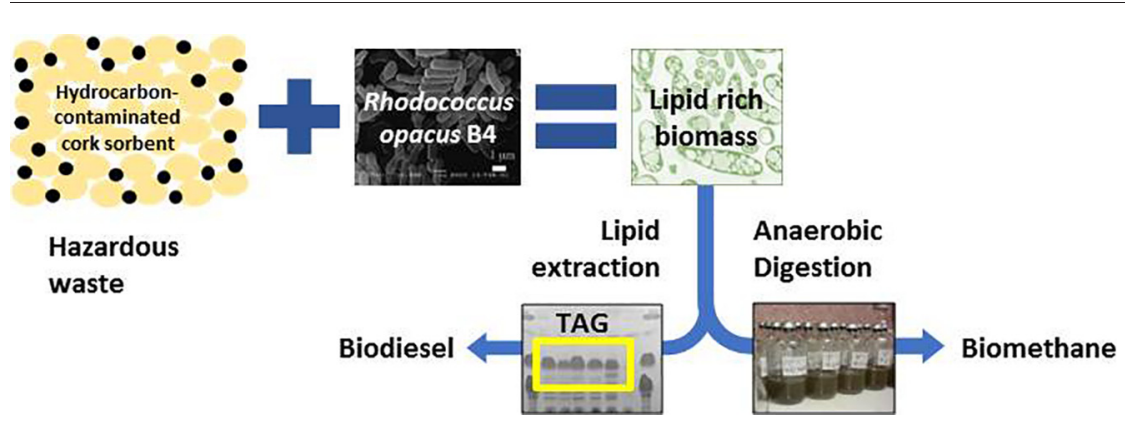

\begin{abstract}
A B S T R A C T
This work demonstrates that cork used as oil-spill sorbents, contaminated with liquid hydrocarbons, herein demonstrated with hexadecane, can be biologically treated by Rhodococcus opacus B4 with concomitant lipids production. R. opacus B4 consumed up to $96 \%$ of hexadecane (C16) impregnated in natural and regranulated cork sorbents after $48 \mathrm{~h}$ incubation, producing $0.59 \pm 0.06 \mathrm{~g}$ of triacylglycerol (TAG) $\mathrm{g}^{-1}$ of $\mathrm{C} 16$ consumed with a TAG content of $0.60 \pm 0.06 \mathrm{~g} \mathrm{~g}^{-1}$ of cellular dry weight (CDW) and $0.54 \pm 0.05 \mathrm{~g} \mathrm{TAG} \mathrm{g}^{-1}$ of $\mathrm{C} 16$ consumed with a TAG content of $0.77 \pm 0.04 \mathrm{~g} \mathrm{~g}^{-1}$ (CDW), respectively. TAG was mainly composed by fatty acids of 16 and 18 carbon chains demonstrating the feasibility of using it as raw material for biodiesel production. In addition, the obtained lipid-rich biomass (whole cells) can be used for biomethane production, at a yield of $0.4 \mathrm{~L}$ $\mathrm{CH}_{4} \mathrm{~g}^{-1}(\mathrm{CDW})$.

The obtained results support a novel approach for management of oil-spill contaminated cork sorbents through its valorisation by producing bacterial lipids, which can be used as feedstocks for biofuels production.
\end{abstract}

(c) 2016 Elsevier B.V. All rights reserved.

\section{Introduction}

Increasing demand for liquid petroleum has intensified industrial activities related to petroleum exploration increasing the risk of oil spillages in land or in marine systems, accidentally or deliberately (Lucas and MacGregor, 2006; Atlas, 1995). Crude oil is mainly composed by a

\footnotetext{
* Corresponding author: Universidade do Minho, Departamento de Engenharia Biológica, Campus de Gualtar, 4710-057 Braga, Portugal.

E-mail address: alcina@deb.uminho.pt (M.A. Pereira).
}

mixture of hydrocarbons, with $>20,000$ chemical components (Marshall and Rodgers, 2003). Release of these compounds into the environment is a serious pollution threat, resulting in a high negative impact on the biotic and abiotic components of the ecosystems (Peterson et al., 2003; Teal and Howarth, 1984). To mitigate this problem, several technologies have been developed to treat hydrocarbon contaminated environments, employing biological, physical, chemical and thermal processes (Hu et al., 2013; Dewling, 1980). Among those, physical containment and recover, using a variety of equipment such as booms, barriers, skimmers, as well as natural and synthetic absorbent materials, 
are usually in the primary line of defence against oil spills. They present some advantages, since can be applied to all types of oils, no maintenance is required and are simple to use (Dave, 2011).

Cork is a good natural absorbent due to their hydrophobic nature (Silva et al., 2005) and is being used as biosorbent material in the treatment of oil spills and leaks (Silva, 2007), oil-in-water emulsions (Souza et al., 2016) and also vegetable oil refinery wastewaters (Pintor et al., 2015). After use, oil contaminated cork residues are treated by conventional physical-chemical methods, having an associated cost.

Rhodococcus are aerobic gram-positive bacteria widely distributed through different environments such as soils, sediments and water (Alvarez et al., 2004; Peng et al., 2008) and particularly in hydrocarbon-contaminated ecosystems (Van Hamme et al., 2003). Because this genus possess many catabolic genes conferring the capacity to transform a wide variety of pollutants including hydrocarbons, (Larkin et al., 2010), several Rhodococcus strains are being study for bioremediation of hydrocarbon-contaminated sites and industrial wastewaters (Auffret et al., 2014). Rhodococcus species are also interesting because they can produce storage lipids compounds, especially TAG, during cultivation on several carbon sources, including single hydrocarbons (Alvarez, 2003) and waste hydrocarbon mixtures (Da Silva et al., 2016). Bacterial lipids are valuable compounds with potential to replace fossil resources in many industrial processes, in particularly in biofuels production.

In this work, biological treatment of hydrocarbon-contaminated cork sorbents for its valorization by bacterial lipids production was assessed using $R$. opacus B4. The suitability of the produced lipids as feedstock for biofuels production, namely biodiesel and biomethane, was further evaluated.

\section{Material and methods}

\subsection{Cork sorbents}

Natural cork and regranulated cork were tested. Natural cork can absorb five times its weight in oil while regranulated cork, due to a thermal treatment at $450{ }^{\circ} \mathrm{C}$ can absorb ten times its weight in oil (Silva, 2007).These products are commercially available under the name CORKSORB (https://www.corksorb.com/en). Both materials were provided by Cortiçeira Amorim, S.A., Portugal.

\subsection{Bacterial strain, media and cultivation conditions}

\subsubsection{Strain and media}

R. opacus B4 (NBRC 108011) was purchased from the National Institute of Technology and Evaluation, Biological Resource Center, Japan (NBRC). This strain was selected due to the ability to produce lipid storage compounds, namely TAG when cultivated on hexadecane $\left(\mathrm{C}_{16} \mathrm{H}_{34}\right)$ (Castro et al., 2016).

Mineral salts (MS) medium was used for cell maintenance and growth (Schlegel et al., 1961). Hexadecane was chosen as a model contaminant since it is usually used as the main representative compound of aliphatic hydrocarbons, one of the dominant groups found in crude oil and derivatives (Pacini-Petitjeana et al., 2015). This compound was used in the assays as carbon and energy source at $1 \mathrm{~g} \mathrm{~L}^{-1}$.

\subsubsection{Preparation of seed culture}

Cells from a single colony of $R$. opacus B4 grown on MS medium agar plates (1.5\% agar) at $30^{\circ} \mathrm{C}$ during 4 days were inoculated in $50 \mathrm{~mL}$ of 802 medium (rich medium) in a $250 \mathrm{~mL}$ flask. The seed culture was incubated on a rotary shaker $(150 \mathrm{rpm})$ at $30^{\circ} \mathrm{C}$ until the middle of the exponential growth phase was reached $(48 \mathrm{~h})$. Growth was determined by measuring optical density at $600 \mathrm{~nm}$ wavelength with a spectrophotometer (U-1500 Hitachi, Tokyo, Japan).

\subsubsection{Growth and lipid accumulation experiments}

The experiments were carried out under sterile conditions, in duplicate, using $250 \mathrm{~mL}$ conical flasks containing $50 \mathrm{~mL}$ of defined medium. The cultures were incubated on a rotary shaker $(150 \mathrm{rpm})$ at $30^{\circ} \mathrm{C}$.

Cells of seed culture were harvested, washed with sterile sodium chloride solution $(0.9 \%, w / v)$, and re-suspended in fresh MS medium. Then, cells were used to inoculate flasks to an optical density at $600 \mathrm{~nm}\left(\mathrm{OD}_{600 \mathrm{~nm}}\right)$ of 0.1 and cultivated in MS medium supplemented with hexadecane $\left(1 \mathrm{~g} \mathrm{~L}^{-1}\right)$ as sole carbon source. Nitrogen was supplied at a molar carbon to nitrogen ratio of $4(\mathrm{C} / \mathrm{N}=4)$. These conditions will promote growth in order to have high amounts of biomass. Cells were grown until the middle of the exponential growth phase which corresponded to $150 \mathrm{~h}$ of cultivation. Cells from the grown inoculum were thereafter collected by centrifugation $\left(4^{\circ} \mathrm{C} ; 10 \mathrm{~min}, 10,000 \mathrm{~g}\right)$, washed twice with sterile sodium chloride solution $(0.9 \%, w / w)$ and transferred to new flasks previously prepared with fresh MS medium and cork contaminated with hexadecane. Considering the maximum absorption capacity of both cork sorbents, $0.01 \mathrm{~g}$ of natural cork or $0.005 \mathrm{~g}$ of regranulated cork granules were weight together with $50 \mathrm{mg}$ of hexadecane (final concentration of $1 \mathrm{~g} \mathrm{~L}^{-1}$ in the culture medium) to the flasks. After $24 \mathrm{~h}$ of contact between cork and hexadecane, MS medium containing nitrogen at a molar $\mathrm{C} / \mathrm{N}$ ratio of 300 (storage lipid accumulation conditions) was added.

In parallel, several control experiments were performed: 1) $R$. opacus B4 growing on MS medium supplemented with hexadecane $0.1 \%(w / v)$ and without cork - B4.C16;2) MS medium supplemented with hexadecane $0.1 \%(w / v)$ and natural cork granules (NC) $\mathrm{NC} \cdot \mathrm{C} 16 ; 3) \mathrm{MS}$ medium supplemented with hexadecane $0.1 \%(w / v)$ and regranulated cork granules (RC) - RC.C16; 4) MS medium supplemented with natural cork granules but without hexadecane - B4 $\cdot \mathrm{NC}$ and 5) MS medium supplemented with regranulated cork granules (RC) but without hexadecane - B4.RC. After 48 h of cultivation, cells were harvested, washed and kept at $-80^{\circ} \mathrm{C}$ until further lyophilisation.

\subsection{Analytical methods}

\subsubsection{Chemical oxygen demand (COD)}

Chemical oxygen demand (COD) was determined using the cuvettetest Lck414 (Hach-Lange, Germany). These measurements were made in triplicate, using the manufacturer's procedures.

\subsection{Hexadecane extraction and quantification}

Hexadecane extraction and quantification was performed according to Castro et al. (2016). Briefly, hexadecane in the culture medium was sequentially extracted from each replicate flask (total content of the flask analyzed) in a separation funnel using hexane as solvent. Hexadecane concentration was determined in a gas chromatograph coupled to a flame ionization detector (GC-FID) (GC Varian ${ }^{\circledR}$ star $3400 C X$, USA). The column used was the model VF-1 ms (Agilent, USA) $30 \mathrm{~m}$ length long $\times 0.025 \mathrm{~mm}$ internal diameter, made from fused silica coated with dimethylpolysiloxane as stationary phase. Helium was used as carrier gas at a flow rate of $1 \mathrm{~mL} \mathrm{~min}^{-1}$. The temperature of the detector and the injector were set at 300 and $285^{\circ} \mathrm{C}$, respectively. The column's temperature was maintained at $60^{\circ} \mathrm{C}$ for $1 \mathrm{~min}$ and then raised up to $290{ }^{\circ} \mathrm{C}$ at a rate of $8{ }^{\circ} \mathrm{C} \mathrm{min}-1$.

\subsection{Extraction and analysis of neutral lipids}

\subsubsection{Total lipid extraction}

Total lipid were extracted from $10 \mathrm{mg}$ of lyophilized cells (or cork granules) using chloroform: methanol $(2: 1 ; v / v)$ as extraction solvent, according to Folch method (Folch et al., 1957). The mixture was incubated at room temperature with shaking for two hours. Afterwards, the lipid extracts were separated from the cells by filtration through glass wool and evaporated to dryness. 


\subsubsection{Neutral lipid analysis and TAG quantification}

Detection of neutral lipids was performed using thin layer chromatography (TLC) according to Alvarez et al. 1996. The solvent system: hexane/diethyl ether/acetic acid (80:20:1, $/ \mathrm{v} / \mathrm{v})$ was used as mobile phase for lipid classes separation. Neutral lipids were detected using iodine vapor as staining reagent. Olive oil, oleic acid, and oleyl oleate were used as standard substances for triacylglycerols (TAG), fatty acids (FA) and wax esters (WE), respectively. TAG fraction was excised from TLC plates, transferred to a Pasteur pipet filled with cotton wool and eluted from the silica, using chloroform as solvent. Chloroform was evaporated and TAG further quantified gravimetrically.

\subsection{Analysis of fatty acid content and composition}

The experimental procedure used for analysis of fatty acid composition of cells and TAG isolated from cells of R. opacus (and from cork granules) was done as described in Brandl et al., 1988 and Timm et al., 1990. Briefly, samples were methylated using a mixture of methanol: sulphuric acid $(85 / 15 \mathrm{v} / \mathrm{v})$ during $3.5 \mathrm{~h}$ at $100^{\circ} \mathrm{C}$. Methyl esters were analyzed in a GC-FID (Varian 3800) equipped with a CP-Sil 52 CB $30 \mathrm{~m} \times$ $0.32 \mathrm{~mm} \times 0.25 \mu \mathrm{m}$ capillary column (Teknokroma, TR-WAX) using splitless mode. The identification of fatty acids was performed comparing the respective retention factor values ( $\mathrm{Rf}$ ) to standard fatty acid methyl esters.

\subsection{Biochemical methane potential (BMP) assays}

\subsubsection{Inoculum and substrate}

Lipid-rich biomass resulting from $R$. opacus B4 cultivation in hexadecane-contaminated cork granules was assessed for the Biochemical Methane Potential. A mixture of disrupted anaerobic granular sludge, obtained from a brewery wastewater treatment plant, and manure $(1: 1, v / v)$ was used as inoculum in all BMP assays. The solids content was $31.9 \mathrm{~g} \mathrm{~L}^{-1}$ of total solids (TS) and $22.4 \mathrm{~g} \mathrm{~L}^{-1}$ of volatile solids (VS). The specific methanogenic activity (SMA) in the presence of acetate (30 mM) was $79.1 \mathrm{~mL} \mathrm{CH} 4$ (STP) $\mathrm{g}^{-1}$ (VS) $\mathrm{d}^{-1}$ as was determined according to Costa et al. (2012).

Each sample was characterized in terms of chemical oxygen demand (COD) and TAG content.

\subsubsection{Experimental procedure}

BMP assays were performed according to Angelidaki et al. (2009). A working volume of $60 \mathrm{~mL}$ and $20 \%(\mathrm{v} / \mathrm{v}$ ) of inoculum were used. The assays were performed at $37{ }^{\circ} \mathrm{C}$. The lipid-rich biomass was added to $120 \mathrm{~mL}$ serum bottles containing basal medium. Basal medium pH was adjusted to 7.0 using sodium hydroxide or hydrochloric acid ( $\left.2 \mathrm{~mol} \mathrm{~L}^{-1}\right)$. The vials were sealed and the headspace flushed with $\mathrm{N}_{2} / \mathrm{CO}_{2}(80: 20 \mathrm{v} / \mathrm{v})$. Prior to the assays, $\mathrm{Na}_{2} \mathrm{~S}_{9} \mathrm{H}_{2} \mathrm{O}$ was added to the basal medium, to a final concentration of $1 \mathrm{mmol} \mathrm{L}^{-1}$. All the assays were performed in triplicate. A blank assay was performed in order to subtract the residual substrate present in the inoculum. Avicel, mainly composed by crystalline cellulose (average particle size $50 \mu \mathrm{m}$ ) was used as control assay. The methane accumulated in the closed serum bottles headspace was measured by gas chromatography (GC) equipped with a flame ionization detector (FID) using a gas tight syringe to sample $500 \mu \mathrm{L}$. Methane production was corrected for standard temperature and pressure (STP) conditions $\left(0{ }^{\circ} \mathrm{C}\right.$ and $\left.1 \mathrm{bar}\right)$. Biochemical methane potential was defined as the volume of methane produced per gram of substrate added to the assays, as expressed in Eq. 1:

$M P=\mathrm{CH}_{4} / g$ substrate $=\frac{\mathrm{Kg} \mathrm{COD}-\mathrm{CH}_{4} \times 350\left(\mathrm{LCH}_{4} / \mathrm{Kg} \mathrm{COD}\right)}{\mathrm{g} \text { substrate added }}$

\subsection{Statistical analysis}

Significant differences between samples were evaluated using two factor analysis of variance (ANOVA), using SPSS 22.0.0 statistic software. Statistical significance was established at the $P<0.05$ level.

\section{Results and discussion}

\subsection{Cork characterization}

Cork sorbents used in this study were characterized in terms of neutral lipid composition (Table 1). TAG content in both materials was low, corresponding to about $7 \%$ and $9 \%$ of its weight in natural and regranulated cork granules, respectively. Regarding fatty acid composition, short to medium length chain saturated and even-numbered fatty acids were mainly detected in both materials, namely caprylic acid (C8:0), capric acid (C10:0), lauric acid (C12:0) and myristic acid (C14:0). In addition, oleic acid (C18:1), a long-chain unsaturated fatty acid, was also detected in natural cork. The presence of fatty acids in cork was already demonstrated by other authors, since they are one of the principal components of the cork extractive fraction, solubilized in low-polarity solvents, and also of suberin (Olivella et al., 2013; Şen et al., 2010).

\subsection{Consumption of hexadecane from contaminated cork sorbents by $R$. opacus B4}

The ability of R. opacus B4 to use hexadecane previously impregnated in the cork sorbents was assessed (Table 2). Since cork has a high affinity for hydrocarbons, a set of control experiments were performed to evaluate hexadecane retention by each type of cork (NC_C16 for natural cork and RC_C16 for regranulated cork granules). For natural cork, it was found that $16 \%( \pm 3 \%)$ of the hexadecane initially added could not be recovered with the extraction procedure, while for regranulated cork granules practically all hexadecane was recovered $(98 \% \pm 3 \%$ recovery). This difference may be related to the existence of larger pores in regranulated cork granules, since high temperatures caused the expansion of cork cells, increasing its porosity and consequently lowering diffusion limitations (Pintor et al., 2012). No changes were detected in hexadecane concentration added to both cork types (experiments NC_C16 and RC_C16) after the $48 \mathrm{~h}$ period of the experiment; the differences observed were within the percentages of hexadecane unrecovered from the cork with the extraction procedure.

In the control experiments containing cork, without hexadecane, and cells of $R$. opacus B4 used as inoculum (initial time), hexadecane in concentrations of $0.256 \mathrm{~g} \mathrm{~L}^{-1}$ and $0.199 \mathrm{~g} \mathrm{~L}^{-1}$ was detected in regranulated cork granules (B4_RC) and in natural cork (B4_NC), respectively. These amounts of hexadecane derived from the growth stage and were probably attached to $R$. opacus B4 cells. In the presence of hydrocarbons, cells of several strains of Rhodococcus tend to aggregate and consequently retain the hydrocarbon between cells due to their high hydrophobicity (Binazadeh et al., 2009). After 48 h of cultivation, almost all residual hexadecane, derived from the growth stage, was consumed by $R$. opacus B4 in the experiment containing natural cork (97.6\%), whereas in the one with regranulated cork granules, only $42.6 \%$ was degraded.

In the assays performed with hexadecane contaminated cork sorbents (B4_NC_C16 and B4_RC_C16) R. opacus B4 was able to consume high levels of hexadecane, namely 94\% in B4_NC_C16 and 96\% in B4_RC_C16. Without cork (B4_C16), 93\% hexadecane consumption was observed. These results clearly revealed that both types of cork did not affect hexadecane degradation by $R$. opacus $\mathrm{B} 4$, indicating that this strain can effectively be used in the treatment of hydrocarboncontaminated cork residues. The ability to access the hexadecane impregnated in the cork may be related to the production of surfactants. These compounds are produced by several strains of Rhodococcus (Pal 
Table 1

Characterization of cork sorbents used in this study.

\begin{tabular}{|c|c|c|c|c|c|c|c|c|c|c|}
\hline \multirow[t]{2}{*}{ Material } & \multicolumn{8}{|c|}{ Relative proportion of fatty acids $(\%, w / w)$} & \multirow{2}{*}{$\begin{array}{l}\text { COD } \\
\left(\mathrm{g} \mathrm{g}^{-1}\right)\end{array}$} & \multirow{2}{*}{$\begin{array}{l}\text { TAG content } \\
\left(\mathrm{g} \mathrm{g}^{-1}\right)\end{array}$} \\
\hline & $\mathrm{C} 8: 0$ & $\mathrm{C} 10: 0$ & $\mathrm{C} 12: 0$ & $\mathrm{C} 14: 0$ & $\mathrm{C} 16: 0$ & C16:1 & C18:0 & C18:1 & & \\
\hline Natural cork (NC) & 16.6 & 29.6 & 17.9 & 13.1 & - & - & - & 22.8 & 0.55 & 0.072 \\
\hline Regranulated cork (RC) & 20.5 & 37.5 & 24.4 & 17.6 & - & - & - & - & 0.45 & 0.091 \\
\hline
\end{tabular}

-Not detected.

et al., 2009; Pirog et al., 2013) and are known to emulsify hydrocarbons, reducing surface tensions and thereby increasing mobility and solubility of hydrocarbons (Al-Tahhan et al., 2000). In fact, it was previously demonstrated that R. opacus B4 is able to stabilize water-in-oil emulsion, promoting the bioconversion of water insoluble compounds, such as hydrocarbons (Honda et al., 2008).

\subsection{Production of neutral lipids from hexadecane-contaminated cork} sorbents by $R$. opacus $B 4$

The capability of R. opacus B4 to accumulate lipid storage compounds at the expense of hexadecane-contaminated cork sorbents was evaluated. Fig. 1 shows the profiles of neutral lipid present in the cells of $R$. opacus B4 under the tested conditions. Generally, TAG were the main storage lipid compounds present, and no wax esters were detected. Free fatty acids were also present in all conditions. A band of unknown identity was detected between TAG and WE standards, especially when cells of $R$. opacus B4 were cultivated with regranulated cork and with natural cork not contaminated with hexadecane (lanes 5 and 6 , respectively).

Table 3 presents TAG contents and yields of $R$. opacus B4 cells in all tested conditions. It was observed that when grown cells of $R$. opacus B4 were transferred to MS medium supplemented with $1 \mathrm{~g} \mathrm{~L}^{-1}$ of hexadecane (B4_C16, initial time), TAG production amounted to $0.34 \mathrm{~g} \mathrm{~g}^{-1}$ cellular dry weight (CDW). This result indicated that TAG accumulation occurred already in the growth stage $(C / N=4)$ and approximately $0.94 \mathrm{mg}$ of TAG accumulated inside the cells were transferred to the next cultivation stage. After $48 \mathrm{~h}$ of cultivation under nitrogen limiting conditions $(C / N=300)$ there was a significant increase of TAG production, reaching $0.47 \mathrm{~g} \mathrm{~g}^{-1} \mathrm{CDW}(p<0.05)$.

When $R$. opacus B4 was cultivated in the presence of each type of cork without the addition of hexadecane, lower amounts of TAG were detected, namely $0.25 \mathrm{~g} \mathrm{~g}^{-1} \mathrm{CDW}$ in B4_NC and $0.08 \mathrm{~g} \mathrm{~g}^{-1} \mathrm{CDW}$ in B4_RC $(p<0.05)$, indicating that this strain preferentially consume the TAG previously stored in the growth stage instead of the residual hexadecane transfer from that stage (57.4\% not used in B4_RC assay, corresponding to $0.147 \mathrm{~g} \mathrm{~L}^{-1}$, Table 2). It has been previously demonstrated that strains of Rhodococcus can mobilize and use the

Table 2

Hexadecane consumption by cells of $R$. opacus B4 cultivated on hexadecane (B4_C16); on hexadecane contaminated natural cork (B4_NC_C16); on hexadecane contaminated regranulated cork (B4_RC_C16); on natural cork (B4_NC) and on regranulated cork (B4_RC) without the addition of hexadecane. Experiments with regranulated cork contaminated with hexadecane ( $\mathrm{RC}$ C16) and with natural cork contaminated with hexadecane (NC_C16) were performed to determine hexadecane retention in cork sorbents.

\begin{tabular}{llrr}
\hline Experiment & \multicolumn{2}{l}{$\begin{array}{l}\text { Hexadecane concentration } \\
\left(\mathrm{g} \mathrm{L}^{-1}\right)\end{array}$} & Hexadecane consumption (\%) \\
\cline { 2 - 3 } & $0 \mathrm{~h}$ & \multicolumn{1}{c}{$48 \mathrm{~h}$} & \\
\hline B4_C16 & $1.07 \pm 0.003$ & $0.08 \pm 0.040$ & $92.45 \pm 7.39$ \\
B4_RC_C16 & $0.92 \pm 0.006$ & $0.02 \pm 0.002$ & $96.04 \pm 0.90$ \\
B4_NC_C16 & $0.81 \pm 0.187$ & $0.04 \pm 0.007$ & $93.94 \pm 0.44$ \\
B4_RC & $0.26^{\mathrm{a}}$ & $0.15 \pm 0.003$ & $42.55 \pm 2.00$ \\
B4_NC & $0.20^{\mathrm{a}}$ & $0.004 \pm 0.001$ & $97.62 \pm 0.37$ \\
NC_C16 & $0.82 \pm 0.028$ & $0.72 \pm 0.050$ & $13.51 \pm 3.38$ \\
RC_C16 & $1.02 \pm 0.268$ & $0.89 \pm 0.378$ & $4.79 \pm 3.24$ \\
\hline
\end{tabular}

a Hexadecane from growth stage. accumulated TAG in the absence of an external carbon source (Alvarez et al., 2000). The results obtained in this study suggest that $R$. opacus B4 uses the stored TAG as carbon source even before the external carbon source, in this case hexadecane, is completely depleted from the medium.

Cells of R. opacus B4 cultivated in the presence of regranulated cork contaminated with hexadecane showed significantly higher TAG levels, namely $0.77 \mathrm{~g} \mathrm{~g}^{-1} \mathrm{CDW}$ (B4_RC_C16), than for natural cork contaminated with hexadecane (B4_NC_C16) which accumulated $0.60 \mathrm{~g} \mathrm{~g}^{-1}$ $\operatorname{CDW}(p<0.05)$. This can be explained by the fact that lower amounts of regranulated cork granules were used in the assays (since it has higher absorption capacity), resulting in a lower total weight of cells and cork than for natural cork contaminated with hexadecane (B4_NC_C16).

TAG yields, expressed as grams of TAG formed per gram of hexadecane consumed by $R$. opacus B4, were similar for both hexadecane-contaminated cork sorbents, reaching $0.54 \mathrm{~g} \mathrm{~g}^{-1}$ and $0.59 \mathrm{~g} \mathrm{~g}^{-1}$ in the presence of contaminated regranulated cork granules and natural cork, respectively. The lowest TAG yields were obtained for $R$. opacus B4 cultivated on non-contaminated cork sorbents, since the only residual amount of hexadecane available was the one transferred from the growth stage.

\subsection{Fatty acid composition of TAG produced by R. opacus B4}

TAG composition in terms of fatty acids is a determinant factor in several industrial applications. The fatty acid composition of TAG fraction in cells of $R$. opacus B4 is presented in Table 4 . In all tested conditions, palmitic acid (C16:0) was the main fatty acid detected, with values ranging from $56 \%$ to $83 \%(w / w)$. These results are in accordance with several works (Alvarez, 2003; Silva et al., 2010), revealing that the main fatty acids produced were directly related to the chain length of the carbon source. The fatty acid composition of TAG fraction

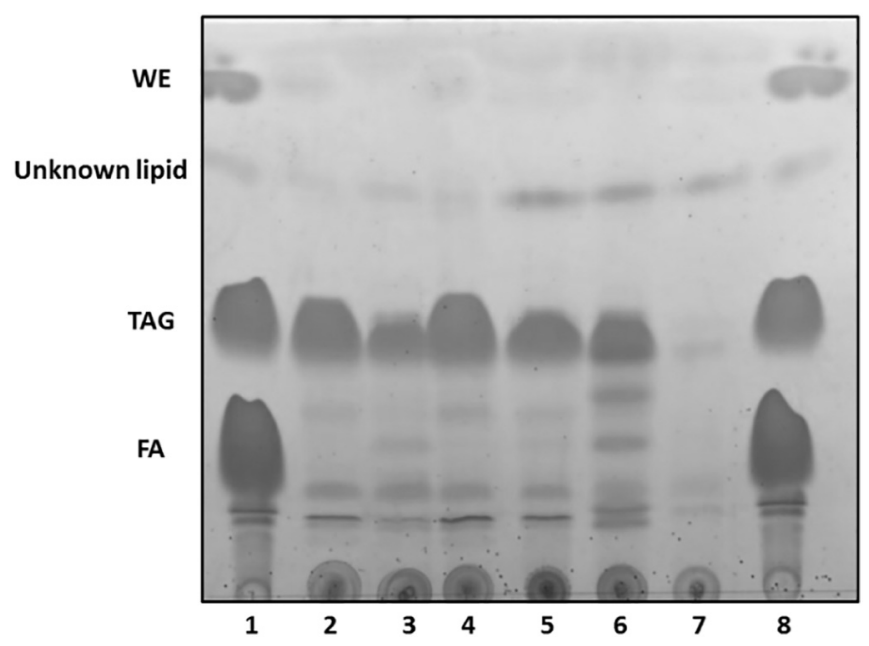

Fig. 1. TLC analysis of neutral lipid compounds present in cells of $R$. opacus B4. Cells were firstly grown on MS medium supplemented with $1 \mathrm{~g} \mathrm{~L}^{-1}$ hexadecane at a molar $\mathrm{C} / \mathrm{N}$ ratio of 4. After growth, cells were transferred to fresh MS medium supplemented with hexadecane $\left(1 \mathrm{~g} \mathrm{~L}^{-1}\right)$ contaminated cork residues with a molar ratio of $\mathrm{C} / \mathrm{N} 300.1$ and 8 - neutral lipids standards; 2 - B4_NC_C16; 3 - B4_C16 (initial time); 4 - B4_C16; 5 B4_RC_C16; 6 - B4_NC; 7 - B4_RC. 
Table 3

TAG content and yields in cells of $R$. opacus B4 cultivated in MS medium at a molar C/N ratio of 300 supplemented with $1 \mathrm{~g} \mathrm{~L}^{-1}$ hexadecane (B4_C16); hexadecane contaminated natural cork (B4_NC_C16); hexadecane contaminated regranulated cork (B4_RC_C16); natural cork (B4_NC) and regranulated cork (B4_RC) after $48 \mathrm{~h}$.

\begin{tabular}{llll}
\hline Experiment & $\begin{array}{l}\text { TAG content } \\
\left(\mathrm{g} \mathrm{g}^{-1} \mathrm{CDW}\right)\end{array}$ & $\begin{array}{l}\text { TAG formed } \\
(\mathrm{mg})\end{array}$ & $\begin{array}{l}\text { TAG yield } \\
\left(\mathrm{g} \mathrm{TAG} \mathrm{g}^{-1} \text { C16 consumed) }\right.\end{array}$ \\
\hline B4_C16 (initial time) & $0.34 \pm 0.15$ & - & - \\
B4_C16 & $0.47 \pm 0.04$ & 22.6 & 0.47 \\
B4_NC_C16 & $0.60 \pm 0.06$ & $25.0 \pm 0.9$ & $0.59 \pm 0.04$ \\
B4_RC_C16 & $0.77 \pm 0.04$ & $25.2 \pm 6.1$ & $0.54 \pm 0.05$ \\
B4_NC & $0.25 \pm 0.03$ & $4.22 \pm 0.3$ & $0.38 \pm 0.03$ \\
B4_RC & $0.08 \pm 0.02$ & 0 & 0 \\
\hline
\end{tabular}

produced from hexadecane-contaminated cork, showed some differences according to the type of cork. In the case of natural cork contaminated with hexadecane (B4_NC_C16), R. opacus B4 did not produce fatty acids shorter than $\mathrm{C} 12: 0$, whereas the longer chain fatty acids (C14 to C18) were most predominant, accounting to $85 \%$ of the total fatty acids. On the other hand, in the experiment performed with hexadecane-contaminated regranulated cork granules (B4_RC_C16) shorter chain fatty acids, namely C8:0; C10:0 and C14:0 were present, although in trace amounts.

The length of the fatty acids chain and level of unsaturation are important TAG characteristics that significantly affect the quality of the produced biofuels (Knothe, 2005). In this study, both hexadecane contaminated cork sorbents promoted accumulation of fatty acids with longer chains by $R$. opacus B4. In particular, natural cork contaminated with hexadecane led to the accumulation of palmitic acid (C16:0); palmitoleic acid (C16:1) and oleic acid (C18:0), making these TAG suitable options for biodiesel production, since they are similar to the ones found in plants and animal oils and improve biodiesel oxidative stability (Meng et al., 2009). Some reports found in the literature corroborate these results, revealing the importance of TAG produced by strains of Rhodococcus in the biodiesel industry (Cortes and de Carvalho, 2015; Kosa and Ragauskas, 2012).

\subsection{Methane production from $R$. opacus B4 lipid-rich biomass}

Lipids are good candidates for biomethane production (Alves et al., 2009). Biomethane is a relevant renewable source; it can meet all technical requirements set by the vehicle manufacturers and natural gas transportation system and use the existing natural gas infrastructure.

In this study, the biochemical methane potential of the obtained lipid-rich biomass (TAG containing cells + cork) was evaluated in batch assays. Fig. 2 presents the obtained cumulative methane production as a function of time.

In all assays, methane production started after the first day of digestion and maximum methane production was achieved within 7 days of incubation. Methane production from $R$. opacus B4 lipid-rich biomass proceeded at a faster rate than Avicel (control), in which residual substrate introduced with the inocula (assessed in the blank assay) seems

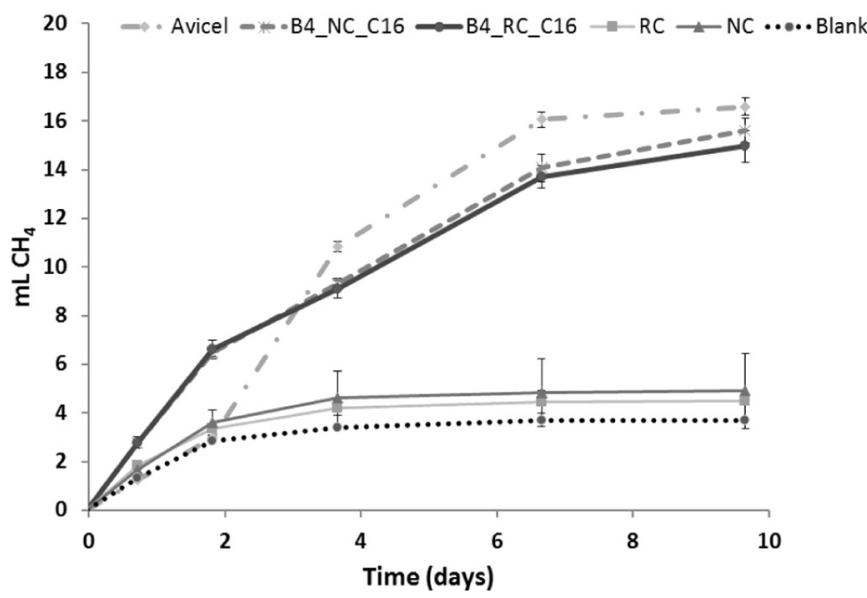

Fig. 2. Cumulative methane production of $R$. opacus $\mathrm{B} 4$ lipid-rich biomass cultivated in hexadecane contaminated regranulated cork sorbent (B4_RC_C16) and in hexadecane contaminated natural cork sorbent (B4_NC_C16), of natural cork (NC) and regranulated cork (RC). Blank: sludge used as inoculum, Avicel: control assay.

to have been firstly converted (plateau reaching about $3 \mathrm{~mL} \mathrm{CH}_{4}$ ). $R$. opacus B4 cultivated on both cork contaminated granules reached similar methane production values, about $0.40 \mathrm{~L} \mathrm{CH}_{4}$ per gram of $\mathrm{CDW}$ (Table 5). However, conversion yield was somewhat lower in the regranulated hexadecane-contaminated cork (B4_RC_C16), where only $71.1 \%$ of COD was converted to methane. Cork sorbents exhibited very low conversion yields, where only $16 \%$ and $32 \%$ of COD were converted to methane in NC and RC, respectively (Table 5).

The results obtained show that bacterial lipid-rich biomass, obtained from biological treatment of hexadecane-contaminated cork sorbents, is efficiently converted to methane. Valorisation of this biomass as feedstock for methane production is a suitable option, with the advantage that the process does not require TAG extraction from cells avoiding the associated processing costs.

Anaerobic digestion is an established, scalable technology that can be used to transform a wide range of organic wastes into methane. Anaerobic degradation of alkanes and other petroleum hydrocarbons proceeds at very slow rate (Berdugo-Clavijo and Gieg, 2014; Embree et al., 2014) making its conversion to methane ineffective. However, when an intermediate step is included to first convert petroleum hydrocarbons into lipids, which are then easily converted to methane, the process is accelerate leading to efficient methane production. This two-steps approach, herein demonstrated with hexadecane-contaminated cork sorbents, opens news perspectives for valorisation of petroleum contaminated wastes and wastewaters through methane production.

\section{Conclusions}

This work demonstrates that cork used as oil-spill sorbents, contaminated with liquid hydrocarbons, herein demonstrated with hexadecane, can be biologically treated by $R$. opacus B4 with

Table 4

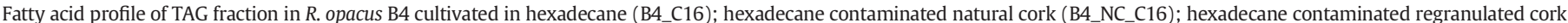
(B4_RC_C16); natural cork (B4_NC) and regranulated cork (B4_RC) under nitrogen limiting conditions (C/N=300) during 48 h.

\begin{tabular}{|c|c|c|c|c|c|c|c|c|}
\hline \multirow[t]{2}{*}{ Experiment } & \multicolumn{8}{|c|}{ Relative proportion of fatty acids $[\%, w / w]$} \\
\hline & C8:0 & $\mathrm{C} 10: 0$ & $\mathrm{C} 12: 0$ & $\mathrm{C} 14: 0$ & $\mathrm{C} 16: 0$ & $\mathrm{C} 16: 1$ & $\mathrm{C} 18: 0$ & C18:1 \\
\hline B4_C16_t0 & - & - & $*$ & $2.6 \pm 0.5$ & $67.4 \pm 4.8$ & $8.1 \pm 2.3$ & $35.2 \pm 5.9$ & $7.8 \pm 3.1$ \\
\hline B4_C16 & - & - & $*$ & $3.7 \pm 0.3$ & $58.6 \pm 1.7$ & $21.6 \pm 3.4$ & $7.2 \pm 1.2$ & $2.8 \pm 0.02$ \\
\hline B4_NC_C16 & - & $*$ & $10.5 \pm 2.2$ & $4.5 \pm 1.2$ & $67.7 \pm 9.7$ & $13.5 \pm 1.5$ & $7.8 \pm 2.4$ & $1.8 \pm 0.4$ \\
\hline B4_RC_C16 & $1.5 \pm 0.2$ & $2.6 \pm 0.7$ & $*$ & $5.5 \pm 1.7$ & $71.5 \pm 11.6$ & $21.0 \pm 9.6$ & $20.9 \pm 3.7$ & $2.8 \pm 0.7$ \\
\hline B4_NC & $6.2 \pm 1.2$ & $1.7 \pm 0.4$ & $1.5 \pm 0.4$ & $6.5 \pm 1.1$ & $82.8 \pm 8.8$ & $10.4 \pm 5.0$ & - & $1.3 \pm 0.2$ \\
\hline B4_RC & - & - & $1.4 \pm 0.6$ & $2.0 \pm 0.3$ & $55.5 \pm 0.6$ & $8.5 \pm 2.8$ & $3.8 \pm 0.6$ & $3.5 \pm 0.6$ \\
\hline
\end{tabular}

-not detected: $*<0.5 \%$ 
Table 5

Biomethane production and conversion yields in R. opacus B4 lipid-rich biomass cultivated in hexadecane contaminated cork sorbents.

\begin{tabular}{lcl}
\hline Experiment & $\begin{array}{l}\text { Biomethane production }^{\mathrm{a}} \\
\left(\mathrm{L} \mathrm{CH}_{4} \mathrm{~g}^{-1} \text { substrate) }\right.\end{array}$ & $\begin{array}{l}\text { Conversion yield } \\
\text { ( } \mathrm{g} \text { COD produced } \mathrm{g}^{-1} \text { COD added) }\end{array}$ \\
\hline B4_NC_C16 & $0.42 \pm 0.023$ & $0.815 \pm 0.04$ \\
B4_RC_C16 & $0.40 \pm 0.023$ & $0.711 \pm 0.04$ \\
NC & $0.034 \pm 0.004$ & $0.158 \pm 0.01$ \\
RC & $0.058 \pm 0.005$ & $0.323 \pm 0.02$ \\
Avicel & $0.51 \pm 0.011$ & $1.05 \pm 0.01$ \\
\hline
\end{tabular}

${ }^{a}$ Biomethane production from blank assay was discounted.

concomitant TAG production. Fatty acid composition of TAG fractions mainly included fatty acids of 16 and 18 carbon chains demonstrating the feasibility of using this TAG as raw material for biodiesel production. Additionally, the obtained lipid-rich biomass (whole cells) can be efficiently used for biomethane production. The obtained results support a novel approach for the management of oil-spill contaminated cork sorbents through its valorisation for bacterial lipids production.

\section{Acknowledgments}

This work was financially supported by the Portuguese Science Foundation (FCT) and European Social Fund (ESF, POPH-QREN) through the grant given to A.R. Castro (SFRH/BD/64500/2009), the FCT Strategic Project of UID/BIO/04469/2013 unit, COMPETE 2020 (POCI-01-0145FEDER-006684) and the project RECI/BBB-EBI/0179/2012 (FCOMP-010124-FEDER-027462) and BioTecNorte operation (NORTE-01-0145FEDER-000004) funded by the European Regional Development Fund under the scope of Norte2020 - Programa Operacional Regional do Norte.

The authors gratefully acknowledge Cortiçeira Amorim, S.A., Portugal, for providing the CORKSORB materials used in this work.

\section{References}

Al-Tahhan, R.A., Sandrin, T.R., Bodour, A.A., Maier, R.M., 2000. Rhamnolipid-induced removal of lipopolysaccharide from Pseudomonas aeruginosa: effect on cell surface properties and interaction with hydrophobic substrates. Appl. Environ. Microbiol. 66 (8), 3262-3268.

Alvarez, H., Mayer, F., Fabritius, D., Steinbuchel, A., 1996. Formation of intracytoplasmic lipid inclusions by Rhodococcus opacus strain PD630. Arch. Microbiol. 165, 377-386.

Alvarez, H., 2003. Relationship between beta-oxidation pathway and the hydrocarbondegrading profile in actinomycetes bacteria. Int. Biodeterior. Biodegrad. 52, 35-42.

Alvarez, H., Kalscheuer, R., Steinbuchel, A., 2000. Accumulation and mobilization of storage lipids by Rhodococcus opacus PD630 and Rhodococcus ruber NCIMB 40126. Appl. Microbiol. Biotechnol. 54 (2), 218-223.

Alvarez, H.M., Silva, R.A., Cesari, A.C., Zamit, A.L., Peressutti, S.R., Reichelt, R., Keller, U. Malkus, U., Rasch, C., Maskow, T., Mayer, F., Steinbüchel, A., 2004. Physiological and morphological responses of the soil bacterium Rhodococcus opacus strain PD630 to water stress. FEMS Microbiol. Ecol. 50 (2), 75-86.

Alves, M.M., Pereira, M.A., Sousa, D.Z., Cavaleiro, A.J., Picavet, M., Smidt, H., Stams, A.J.M., 2009. Waste lipids to energy: how to optimize methane production from longchain fatty acids (LCFA). Microb. Biotechnol. 2 (5), 538-550.

Angelidaki, I., Alves, M., Bolzonella, D., Borzacconi, L., Campos, J.L., Guwy, A.J., Kalyuzhnyi, S., Jenicek, P., van Lier, J.B., 2009. Defining the biomethane potential (BMP) of solid organic wastes and energy crops: a proposed protocol for batch assays. Water Sci. Technol. 59 (5), 927-934.

Atlas, R.M., 1995. Petroleum biodegradation and oil spill bioremediation. Mar. Pollut. Bull. 31, 178-182.

Auffret, M., Yergeau, E., Labbé, D., Fayolle-Guichard, F., Greer, C., 2014. Importance of Rhodococcus strains in a bacterial consortium degrading a mixture of hydrocarbons, gasoline, and diesel oil additives revealed by metatranscriptomic analysis. Appl. Microbiol. Biotechnol. 1-12.

Berdugo-Clavijo, C., Gieg, L., 2014. Conversion of crude oil to methane by a microbial consortium enriched from oil reservoir production waters. Front. Microbiol. 5 (167), 1.

Binazadeh, M., Karimi, I.A., Li, Z., 2009. Fast biodegradation of long chain n-alkanes and crude oil at high concentrations with Rhodococcus sp. Moj-3449. Enzym. Microb. Technol. 45 (3), 195-202.

Brandl, H., Goss, R.A., Lenz, R.W., Fuller, R.C., 1988. Pseudomonas oleovorans as a source of poly(beta-hydroxyalkanoates) for potential applications as biodegradable polyesters. Appl. Environ. Microbiol. 54, 1977-1982.

Castro, A.R., Rocha, I., Alves, M.M., Pereira, M.A., 2016. Rhodococcus opacus B4: a promising bacterium for production of biofuels and biobased chemicals. AMB Express 6 (1), 35.
Cortes, M.A.L.R.M., de Carvalho, C.C.C.R., 2015. Effect of carbon sources on lipid accumulation in Rhodococcus cells. Biochem. Eng. J. 94 (0), 100-105.

Costa, J.C., Gonçalves, P.R., Nobre, A., Alves, M.M., 2012. Biomethanation potential of macroalgae Ulva spp. and Gracilaria spp. and in co-digestion with waste activated sludge. Bioresour. Technol. 114, 320-326.

Da Silva, P.D.M.P., Lima, F., Alves, M.M., Bijmans, M.F.M., Pereira, M.A., 2016. Valorization of lubricant-based wastewater for bacterial neutral lipids production: growth-linked biosynthesis. Water Res. 101, 17-24.

Dave, D.G., 2011. Remediation technologies for marine oil spills: a critical review and comparative analysis. Am. J. Environ. Sci. 7, 423-440.

Dewling, R.T., 1980. Chemical treatment of oil spills. Environ. Int. 3 (2), 155-162.

Embree, M., Nagarajan, H., Movahedi, N., Chitsaz, H., Zengler, K., 2014. Single-cell genome and metatranscriptome sequencing reveal metabolic interactions of an alkanedegrading methanogenic community. ISME J. 8, 757-767.

Folch, J., Lees, M., Sloane Stanley, G., 1957. A simple method for the isolation and purifcation of total lipides from animal tissues. J. Biol. Chem. 226, 497-509.

Honda, K., Yamashita, S., Nakagawa, H., Sameshima, Y., Omasa, T., Kato, J., Ohtake, H., 2008. Stabilization of water-in-oil emulsion by Rhodococcus opacus B-4 and its application to biotransformation. Appl. Microbiol. Biotechnol. 78 (5), 767-773.

Hu, G., Li, J., Zeng, G., 2013. Recent development in the treatment of oily sludge from petroleum industry: a review. J. Hazard. Mater. 261, 470-490.

Knothe, G., 2005. Dependence of biodiesel fuel properties on the structure of fatty acid alkyl esters. Fuel Process. Technol. 86 (10), 1059-1070.

Kosa, M., Ragauskas, A., 2012. Bioconversion of lignin model compounds with oleaginous Rhodococci. Appl. Microbiol. Biotechnol. 93 (2), 891-900.

Larkin, M., Kulakov, L., Allen, C.R., 2010. Genomes and plasmids in Rhodococcus. In: Alvarez, H.M. (Ed.), Biology of Rhodococcus. vol. 16. Springer, Berlin Heidelberg pp. 73-90.

Lucas, Z., MacGregor, C., 2006. Characterization and source of oil contamination on the beaches and seabird corpses, Sable Island, Nova Scotia, 1996-2005. Mar. Pollut. Bull. 52 (7), 778-789.

Marshall, A.G., Rodgers, R.P., 2003. Petroleomics: the next grand challenge for chemical analysis. Acc. Chem. Res. 37 (1), 53-59.

Meng, X., Yang, J., Xu, X., Zhang, L., Nie, Q., Xian, M., 2009. Biodiesel production from oleaginous microorganisms. Renew. Energy 34 (1), 1-5.

Olivella, M.À., Jové, P., Bianchi, A., Bazzicalupi, C., Cano, L., 2013. An integrated approach to understanding the sorption mechanism of phenanthrene by cork. Chemosphere 90 (6), 1939-1944.

Pacini-Petitjeana, C., Faure, P., Burkle-Vitzthumc, V., Randi a, A., Jacques Pironon, J., 2015 Oxidation of N-hexadecane and crude oil in response to injection of a $\mathrm{CO} 2 / \mathrm{O} 2 \mathrm{mix}$ ture under depleted reservoir conditions: experimental and kinetic modeling preliminary results. Int. J. Greenhouse Gas Control 35, 110-119.

Pal, M., Vaidya, B., Desai, K., Joshi, R., Nene, S., Kulkarni, B., 2009. Media optimization for biosurfactant production by Rhodococcus erythropolis MTCC 2794: artificial intelligence versus a statistical approach. J. Ind. Microbiol. Biotechnol. 36 (5), 747-756.

Peng, F., Wang, Y., Sun, F., Liu, Z., Lai, Q., Shao, Z., 2008. A novel lipopeptide produced by a Pacific Ocean deep-sea bacterium, Rhodococcus sp. TW53. J. Appl. Microbiol. 105 (3) 698-705.

Peterson, C.H., Rice, S.D., Short, J.W., Esler, D., Bodkin, J.L., Ballachey, B.E., Irons, D.B., 2003 Long-term ecosystem response to the Exxon Valdez oil spill. Science 302 (5653), 2082-2086.

Pintor, A.M.A., Ferreira, C.I.A., Pereira, J.C., Correia, P., Silva, S.P., Vilar, V.J.P., Botelho, C.M.S Boaventura, R.A.R., 2012. Use of cork powder and granules for the adsorption of pollutants: a review. Water Res. 46 (10), 3152-3166.

Pintor, A.M.A., Martins, A.G., Souza, R.S., Vilar, V.J.P., Botelho, C.M.S., Boaventura, R.A.R., 2015. Treatment of vegetable oil refinery wastewater by sorption of oil and grease onto regranulated cork - a study in batch and continuous mode. Chem. Eng. J. 268, 92-101.

Pirog, T., Sofilkanych, A., Shevchuk, T., Shulyakova, M., 2013. Biosurfactants of Rhodococcus erythropolis IMV Ac-5017: synthesis intensification and practical application. Appl. Biochem. Biotechnol. 170 (4), 880-894.

Schlegel, H., Kaltwasser, H., Gottschalk, G., 1961. Ein Submersverfahren zur Kultur wasserstoffoxidierender Bakterien: Wachstumsphysiologische Untersuchungen. Arch. Mikrobiol. 38, 209-222.

Sen, A., Miranda, I., Santos, S., Graça, J., Pereira, H., 2010. The chemical composition of cork and phloem in the rhytidome of Quercus cerris bark. Ind. Crop. Prod. 31 (2), 417-422.

Silva, S.P.R., 2007. In: Indústria, C.A. (Ed.), Meio de Absorção/Adsorção à Base de Derivados de Cortiça para Absorção/Adsorção de Óleos. vol. PT103492 (Portugal).

Silva, S.P., Sabino, M.A., Fernandes, E.M., Correlo, V.M., Boesel, L.F., Reis, R.L., 2005. Cork: properties, capabilities and applications. Int. Mater. Rev. 50 (6), 345-365.

Silva, R.A., Grossi, V., Olivera, N.L., Alvarez, H.M., 2010. Characterization of indigenous Rhodococcus sp. 602, a strain able to accumulate triacylglycerides from naphthyl compounds under nitrogen-starved conditions. Res. Microbiol. 161 (3), 198-207.

Souza, R.S., Porto, P.S.S., Pintor, A.M.A., Ruphuy, G., Costa, M.F., Boaventura, R.A.R., Vilar, V.J.P., 2016. New insights on the removal of mineral oil from oil-in-water emulsions using cork by-products: effect of salt and surfactants content. Chem. Eng. J. 285, 709-717.

Teal, J.M., Howarth, R.W., 1984. Oil spill studies: a review of ecological effects. Environ. Manag. 8 (1), 27-43.

Timm, A., Byrom, D., Steinbüchel, A., 1990. Formation of blends of various poly(3hydroxyalkanoic acids) by a recombinant strain of Pseudomonas oleovorans. Appl. Microbiol. Biotechnol. 33, 296-301.

Van Hamme, J.D., Singh, A., Ward, O.P., 2003. Recent advances in petroleum microbiology. Microbiol. Mol. Biol. Rev. 67 (4), 503-549. 